\title{
Commentary: We have the opportunity to be above average
}

\author{
Joseph C. Cleveland, Jr, MD
}

\footnotetext{
From the Division of Cardiothoracic Surgery, Department of Surgery, University of Colorado Anschutz Medical Center, Aurora, Colo.

Disclosures: Author has nothing to disclose with regard to commercial support.

Received for publication May 3, 2019; accepted for publication May 6, 2019; available ahead of print June 18, 2019.

Address for reprints: Joseph C. Cleveland, Jr, MD, Frederick and Carol Grover Endowed Chair in Surgery, Faculty Affairs, Division of Cardiothoracic Surgery, Department of Surgery, University of Colorado Anschutz Medical Center, 12631 E 17th Ave, Building A01, Room 6602, MS C-310, Aurora, CO 80045 (E-mail: joseph. cleveland@ucdenver.edu).

J Thorac Cardiovasc Surg 2020;159:1792-3

$0022-5223 / \$ 36.00$

Copyright (c) 2019 by The American Association for Thoracic Surgery

https://doi.org/10.1016/j.jtcvs.2019.05.008
}

Author and humorist Garrison Keller used to close his regular radio monologue with the tag, "That's the news from Lake Wobegon, where all the women are strong, all the men are good-looking, and all the children are above average." In this mythical place where everyone and everything seems uniquely above average, the cardiac surgery programs of Lake Wobegon would all clearly be performing better than expected.

In this issue of the Journal, Worrall and colleagues ${ }^{1}$ explore this notion, questioning whether every cardiac surgery program is indeed a high-performing program. Indeed, their multifaceted surgeon-led quality improvement initiative examined their cardiac surgery program in their health care system. What they found in 2014 is that the riskadjusted observed mortality for coronary artery bypass grafting $(\mathrm{CABG})$ was higher than expected. In plain language, they observed a signal that their outcomes for CABG were not as good as they had thought. With this recognition, they initiated a thoughtful, thorough, and health care system-wide initiative to improve their CABG mortality. In a 3-year period from 2014 to 2017, they demonstrated a $50 \%$ reduction in observed to expected mortality for CABG. The strengths of this analysis include (1) use of the Society of Thoracic Surgeons risk models and definitions for calculating expected mortality and morbidity with the use of risk-adjusted data; (2) surgeon-leaders who engaged a multifaceted key stakeholder process to provide ongoing support for this project; and (3) unblinding the data and requiring underperforming programs to provide written corrective action plans. In summary, this surgeon-led initiative challenged all programs in their health care system to monitor outcomes continuously and act on the data.

Outcomes of CABG are arguably some of the most rigorously examined quality metrics in medicine. Several different models of reporting and quality initiatives exist. The first of these models included mandatory reporting of CABG mortality in New York State. ${ }^{2}$ Several states now mandate public reporting of $\mathrm{CABG}$ mortality. A variety of Surgeons database. ${ }^{6}$

\section{References} 1779-91.

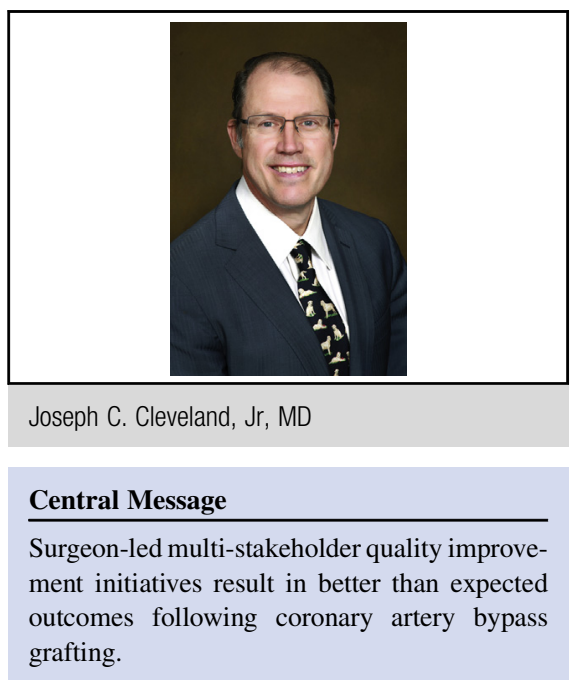

See Article page 1779 .

regional, voluntary collaborative networks - The Northern New England, ${ }^{3}$ Michigan Society of Thoracic and Cardiovascular Surgeons, ${ }^{4}$ and Virginia Cardiac Surgery Quality Initiative ${ }^{5}$ - all have coordinated and published quality initiatives that have led to system-wide improvements in coronary artery bypass outcomes. Finally, the Society of Thoracic Surgeons National Adult Cardiac Database serves as the widest and most far-reaching example of a quality improvement program, with more than $95 \%$ of programs in the United States reporting to the Society of Thoracic

We thus return to the notion that with honest and critical analyses of one's cardiac surgery program, substantial improvements can be made to optimize outcomes. This report in the Journal offers a concrete example of how to effect change in a health care system. The first observation that Worrall and colleagues ${ }^{1}$ made is perhaps the most important. We cannot all perform better than expected. We all, however, have the opportunity to perform better than expected when we systematically analyze how we can improve and create actionable plans with accountability. With thoughtful analysis of risk-adjusted outcomes, we can offer our patients who undergo $\mathrm{CABG}$ the best chance for being alive and well.

1. Worrall N, Brevig J, Jin R, Gluckman T, Hunter R, Ducsik M, et al. Reduction in coronary artery bypass grafting surgery mortality and morbidity during a 3-year multicenter quality improvement project. J Thorac Cardiovasc Surg. 2020;159:

2. Chassin MR. Achieving and sustaining improved quality: lessons from New York state and cardiac surgery. Health Aff (Millwood). 2002;21:40-51. 
3. O'Connor GT, Plume SK, Olmstead EM, Morton JR, Maloney CT, Nugent WC, et al. A regional intervention to improve the hospital mortality associated with coronary artery bypass graft surgery. The Northern New England cardiovascular disease study group. JAMA. 1996;275:841-6.

4. Johnson SH, Theurer PF, Bell GF, Maresca L, Leyden T, Prager RL, Michigan Society of Thoracic and Cardiovascular Surgeons. A statewide quality collaborative for process improvement: internal mammary artery utilization. Ann Thorac Surg. 2010;90:1158-64.
5. Rich JB, Fonner CE, Quader MA, Ailawadi G, Speir AM. Impact of regional collaboration on quality improvement and associated cost savings in coronary artery bypass grafting. Ann Thorac Surg. 2018;106: 454-9.

6. D'Agostino RS, Jacobs JP, Badhwar V, Fernandez FG, Paone G, Wormuth DW, et al. The Society of Thoracic surgeons adult cardiac surgery database: 2019 update on outcomes and quality. Ann Thorac Surg. 2019; 107:24-32. 